\title{
Deconstructing the Map after 25 Years: Furthering Engagements with Social Theory
}

Article in Cartographica The International Journal for Geographic Information and Geovisualization · March 2015 DOI: $10.3138 /$ carto.50.1.10

CITATIONS

0

1 author:

\section{Leila M. Harris}

University of British Columbia - Vancouver

88 PUBLICATIONS 873 CITATIONS

SEE PROFILE
READS

46

Some of the authors of this publication are also working on these related projects: 


\section{Deconstructing the Map After 25 Years: Furthering Engagements with Social Theory}

\section{Leila Harris}

Corresponding Author: Iharris@ires.ubc.ca

Final version: Harris, L. (2015) Deconstructing the Map after 25 Years: Furthering Engagements with Social Theory. Cartographica 50(1): 50-53

Citations of this work should use the final version as noted above 


\section{TABLE OF CONTENTS}

Deconstructing the Map After 25 Years: Furthering Engagements With Social Theory .. 1

References. 6 


\section{DECONSTRUCTING THE MAP AFTER 25 YEARS: FURTHERING ENGAGEMENTS WITH SOCIAL THEORY}

The introductory paragraphs of "Deconstructing the Map" clearly spell out Harley's aim. As he writes, "we should encourage an epistemological shift in the way we interpret the nature of cartography" $(1989,1)$. A quarter century later, it is clear that this imperative has generally been well heeded-we read, interpret, and theorize maps differently. As other contributors to this volume make clear, due to technological and other shifts, we also engage in mapmaking very differently. Following from the postmodernist and deconstructivist turn, elements of Harley's core concern no longer appear to be central. We no longer simply accept "what cartographers tell us maps are supposed to be" $(1989,1)$. Rather, there is deep and thoughtful questioning, critique, and genealogical investigation of how particular maps came to be, or what they represent (and do not represent). Importantly, a large number of works in the history of cartography and critical cartographic traditions have also taken up Harley's invitation to think carefully about the social and political effects of cartography and particular maps as imparting "a sense of the world." Recent interventions along these lines also foreground the effects that maps have for users, societies, or socio-natures. While I certainly recognize that this sort of critical gaze has not permeated all dimensions of cartographic theory and practice, it is undeniable that Harley's work has been a strong guidepost in establishing these as key concerns for ongoing work.

In this brief essay, I aim to first detail and celebrate several aspects of Harley's interventions, noting a few features of the text that remain highly apposite, particularly from my perspective as a scholar of nature-society and social justice. It is important to note from the outset that I am not a cartographer, and do not consider mapping to be elemental to my work. Yet, when I read "Deconstructing the Map" some years ago, it nonetheless colored how I thought about and approached other relationships and processes more core to political ecology, environmental justice and other of my research foci. After highlighting some of the ways I have engaged with critical cartographic work (largely in relation to conservation mapping and political ecology, together with Helen Hazen), I move quickly to the main interest of the essay. That is to turn to several points of engagement that might help us move beyond some of Harley's key insights and invitations. Specifically, in his discussion of deconstruction, Harley signals an interest in "aporias, blind spots, or moments of self contradiction-those unsettling forces 'at the margins"' (1989, 8-9). Given that a major contribution of his work was to bring social theory to discussions in cartography, I am left wondering about other frontiers and social theoretical influences that might offer productive points of engagement for ongoing work in this field.

Highlighting several social theoretical avenues of inquiry that remain "at the margins" for much of critical cartographic inquiry, I highlight potential intersections with feminist and queer theory (notably the work of Butler), with nature-society worknotably interest in posthumanism and the "more than human," as well as potential insights from postcolonial scholars and concepts (for instance, from the work of Spivak). 
While some progress along these lines has already been made, my interest in highlighting these openings is to invite further thinking along these lines. Doing so serves to respond to the need that Harley lays out to continue "to search for the social forces that have structured cartography and to locate the presence of power-and its effects - in all map knowledge" $(1989,2)$. In brief, I ask: beyond poststructuralist influences of direct interest to Harley (e.g., Derrida, Foucault), are there other productive openings that might be offered by feminist, queer, posthumanist, or postcolonial thought? If so, what types of questions and insights might be offered "at the margins" to continue to "unmap" and rethink cartographic epistemologies and products otherwise?

Before turning to these potential openings, it is worth reiterating a few aspects of Harley's work, and the entire body of work on critical cartography that it fostered, that have proven to be of particular interest for my own fields of interest-social justice and nature-society studies. Among other things, and most obviously, Harley's work has been instrumental in enlivening an appreciation for the power-laden features of mapping practice and products, including the ways that certain ways of knowing or world views might be privileged by particular cartographic practices. As well, and linked to this, insights from this work have been foundational for work on counter-mapping, as well as participatory mapping and GIS, as key techniques to unsettle these power geometries and make cartography more available and useful to underserved and marginalized populations (see Elwood, this issue). In a more general sense, a key insight has also been to subject cartography to increasing scrutiny, rather than accepting it as objective, scientific or apart from social and political influences. Instead, many increasingly see cartography and GIS as particularly power-laden, given the simplifications and "truths" that cartography often enables (see special issue of ACME, Harris and Harrower 2006). Finally, as I pick up further below, from a nature-society perspective, Harley's insights related to the effects of particular mapping practices and forms on society have also opened up spaces of inquiry in terms of social understandings of "nature," as well as the effects of mapping and associated territorialization for diverse species or conservation agendas (Harris and Hazen 2006). Now, I turn to my central concern-to further think through other related social theoretical influences and openings-specifically those associated with feminist/queer, nature-society, or postcolonial work and what these might offer to further enrich the approach and contributions associated with "deconstructing the map."

Regarding feminist and queer theory, it is clear that further engagement along these lines might serve to bring light to the gender implications and power dimensions of mapping. This is a theme that has been explored in the literature (Kwan 2002; Rocheleau et al. 1995; Pavlovskaya and St. Martin 2007; Brown and Knopp 2008), but where undoubtedly more could be done. Queering the map, in its most general sense, moves us beyond querying the effects of maps for queer populations or practices, and instead offers an entry point to unsettle some of the normative assumptions of mapping practice (in some ways, exactly the move that Harley invited a quarter century ago). Also learning from feminist and queer theory, concepts such as performativity have been taken up in useful ways to think about how maps work, not as static products, but in ways that are performative-read, reread, and used in ways that subtlely but 
meaningfully alter the maps and their effects over time (Del Casino and Hannah 2005; Kitchin and Dodge 2007; Harris and Hazen 2009, see discussion in introduction by Rose-Redwood, this issue). A key insight from this work relates to the ways that maps may appear stable and fixed (with the power dynamics that this implies), even as they are unstable and continually remade (including with each reading and re-reading in ways that are dependent on the specifics of the reader, or of the time and place where the map is being used and interpreted). Yet, "even if a map is 'remade' with each reading, use, or engagement, there are still ways in which maps appear to cement or stabilize particular socio-spatial relations. This is consistent with discussions of maps in terms of their tendency to convey certainty or control, provide reassurance, or cement particular power dynamics" (Perkins 2006, as cited in Harris and Hazen 2009, 55). I highlight these contributions and foci not only to say that these insights are useful extensions of Harley's work, but also to suggest that these conceptual openings could likely offer still more room for manoeuver to extend and enrich debates in critical cartography. I also wonder, more fundamentally, if these insights open more space for critical inquiry and questioning related to some of the aporias and blind spots in Harley's own work. While Harley attempts to challenge and unsettle cartography, what types of assumptions and biases remain unchallenged and taken as given (including the types of openings that a queer reading of mapping practice might expose in terms of thinking and doing mapping "otherwise")? Some of these openings are highlighted in the introductory essay, and throughout this edited collection, but it remains an open question (and invitation) to consider what other careful readers informed by theoretical approaches in feminist and queer theory might offer to push these issues further still.

Turning to work on posthumanism, animal geographies, or more-than-human debates, this is also a topic where there have been some important insights, yet also some aspects that have likely been missed with key opportunities yet to surface. In terms of work to date, earlier collaborative work with Helen Hazen has highlighted some of the ways that mapping practices have important effects for the more-than-human world (i.e., including diverse species of biomes, Harris and Hazen 2006, 2009; Hazen and Harris 2007). Among other things, we argue that mapping is particularly important in cementing an over-focus on territorial approaches to conservation practice, in ways that sediment "fixed" and inflexible approaches-features that are particularly ill-suited to the dynamics and changes inherent to the biophysical world and to ongoing conservation challenges. Other examples also invite rethinking related to the power and features of mapping practice and products from a posthumanist perspective. For instance, consider Sundberg's $(2011,318)$ assertion that there is a need to understand "nonhumans as actors in geopolitical processes such as boundary making and enforcement." As such, and combined with insights from earlier work on these themes, there is likely more thinking and critical evaluation to be done to enliven understandings at the intersection of critical cartography, nature-society, post-humanist, and more-thanhuman perspectives. Given that mapping has clear influence for societies, what of "socio-natures" and non-human worlds? What are the implications of this for the ways that we think about, and engage in, cartographic practice and critique? Are there ways that we might take more-than-human actors seriously in terms of the effects of maps, but also to rethink map-making practices? 
Turning now to postcolonial and decolonial thought, again, I offer these lines of inquiry not in a definitive sense, but rather to invite further thinking and elaboration. Specifically, in re-reading "Deconstructing the Map," I am left wondering about Harley's understanding of deconstruction, and what closer engagement with work from other postcolonial and decolonial scholars might bring to this approach. Per Walsh $(2012,12)$ one definition of decoloniality is to confront Western or hegemonic thinking, to challenge it, and to consider different modes of thought "constructed and positioned from 'other' histories and subjectivities." Similarly, postcolonial thinking foregrounds relations of coloniality, and related differences (e.g., development), in thinking through and challenging axiomatic understandings based on visions, understandings, and histories of the North, of Europe, or of the metropole. Bringing these approaches to bear on critical cartography, we might ask: what might a stronger focus on North-South relations, or on politics of inequality and power dynamics on regional and global scales, bring to a broadened understanding of cartography and its multiple power effects? Likewise, what might these approaches suggest in terms of connections between mapping practices and products and broader circuits of inequality, such as those related to poverty, development, racism, or colonialism? For example, when Power $(2006,27)$ writes of the "cartographies of development" he suggests the critical need to consider "how development itself operates as a cultural process, and how development institutions, processes, and practices are inevitably caught up in a web of cultural presuppositions, values and meanings."

Clearly, cartography is wrapped up in authoring and cementing meanings and visions of the world. Consider, for a moment, Edward Said's pivotal work, Orientalism (1978), in which he highlighted the power of literary representations in constructing certain "geographical imaginaries." Maps are at least as powerful, if not more so, in constructing visions and understandings of the world and and linked conceptual axes (North-South, developed-undeveloped, wealthy-impoverished, and so forth). As such, it is of interest to rethink and critically assess cartography's relationships with framing particular regions and ways of being in the world. It is also notable that cartographic metaphors remain very commonly used in postcolonial writings, for instance invoking the role of mapping in "writing the world," serving to justify warfare, or to solidify perceptions of certain people and places (e.g., of Iraq as a desert wasteland, Gregory 2004). Consider as well Other Asias by Gayatri Spivak (2008). In that contribution, Spivak interrogates the terminology and mapping of "Asia" and aims to unfix the European understandings that are so central to this referent. She continues, "historically it has always been the powerful who have spoken or been spoken of. ... I am used to looking at the pores of elite texts to tease out excluded itineraries. As we move eastwards, the nature of the texts changes." Some of the exciting work in critical cartography has been precisely to interrogate what counts as a map, and what ways there might be to think about spatial relations or mapping practices "otherwise" in ways that rewrite power relations and cartographies (Sparke 1995, 1998). What other concepts and approaches associated with postcolonial and decolonial work might also be fruitful for further exposing the aporias and silences in mapping, including what counts as a map at all? What types of ambivalent and power-laden knowledges, experiences, or emotions might particular maps produce and invite from the reader, at once foreclosing others? 
I very purposefully have not sought to delineate any clear and vivid pathways for future work on these themes. Rather, I am struck by Harley's key opening to social theory in "Deconstructing the Map," and I am using this invitation to consider what other social theoretical moves might invite yet other insights and avenues for engagement. While we have promising openings in all of these directions, I cannot help but think that there is further work to be done to further resituate and challenge cartographic epistemologies and products, pushing forward with our ability to understand and engage the power and textuality of maps. Another opening that is clear in Harley's words, but that also seems to be a particular vivid and powerful locus of contemporary work relates to the intersection of art and mapping. This relates to the ways that the artistry of mapping might evoke particular feelings or relations, or the ways that we might engage publics in mapping as an artistic and critical political practice. As two brief examples, consider the Amsterdam Realtime project that used GPS data to create bikers' "maps of the city," real-time digital maps showing how bikers use and navigate urban space (discussed by Propen 2006). Yet other inspiring examples exist, such as the efforts of the Los Angeles Urban Rangers to create maps to show public spaces and access points in ways that counter private property claims, or similarly performance art and "tours" that enable new experiences of the city for those who participate (LA Urban Rangers 2014). These types of examples offer still other insights and openings related to how we might further engage communities in mapping practice, drawing on a broad theoretical as well as artistic repertoire to enrich our understanding, and with it, our potential to build other possible worlds. 


\section{REFERENCES}

Brown, M., and L. Knopp. 2008. "Queering the Map: The Productive Tensions of Colliding Epistemologies." Annals of Association of American Geographers, 98(1): 40-58.

Gregory, D. 2004. The Colonial Present: Afghanistan, Palestine, Iraq. Malden, MA: Blackwell.

Harris, L., and M. Harrower, ed. 2005. Special Issue on Critical Cartographies. ACME: An International E-Journal for Critical Geographies 4(1): 1-171.

Harris, L., and H. Hazen. 2009. "Rethinking Maps from a More-Than-Human Perspective: Nature-Society, Mapping, and Conservation Territories." In Rethinking Maps: New Frontiers in Cartographic Theory, ed. M. Dodge, R. Kitchin, and C. Perkins, 50-67. London: Routledge.

- 2006. "Power of Maps: (Counter)mapping for Conservation." ACME: An International E-Journal of Critical Geographies 4(1): 99-130.

Hazen, H., and L. Harris. 2007. "The Limits of Territorially Based Conservation: a Critical Assessment Based on Cartographic and Geographic Approaches." Environmental Conservation 35(1): 1-11.

Kwan, M.-P. 2002. "Feminist Visualization: Re-envisioning GIS as a Method in Feminist Geographic Research." Annals of the Association of American Geographers 92(4): 645-661.

Los Angeles Urban Rangers. 2014. Website, last accessed July 3, 2014. http://laurbanrangers.org/site/

Pavlovskaya, M., and K. St. Martin. 2007. "Feminism and GIS: From a Missing Object to a Mapping Subject." Geography Compass 1(3): 583-606.

Power, M. 2006. "Anti-Racism, Deconstruction and 'Overdevelopment." Progress in Development Studies 6(1): 24-39.

Rocheleau, D., B. Thomas-Slayter, and D. Edmunds. 1995. "Gendered Resource Mapping: Focusing on Women's Spaces in the Landscape." Cultural Survival Quarterly 18(4): 62-68.

Said, E. 1978. Orientalism. New York: Vintage.

Sparke, M. 1995. "Between Demythologizing and Deconstructing the Map: Shawnadithit's New-Found-Land and the Alienation of Canada." Cartographica 32(1): 1-21.

Sparke, M. 1998. "A Map that Roared and an Original Atlas: Canada, Cartography, and the Narration of Nation." Annals of the Association of American Geographers 88(3): 463-495. 
Spivak, G. C. 2008. Other Asias. Malden, MA: Blackwell.

Sundberg, J. 2011. "Diabolic Caminos in the Desert and Cat Fights on the Río: A Posthumanist Political Ecology of Boundary Enforcement in the United StatesMexico Borderlands." Annals of Association of American Geographers 101(2): 318-336.

Walsh, C. 2012. "'Other' Knowledges, 'Other' Critiques: Reflections on the Politics and Practices of Philosophy and Decoloniality in the 'Other' America." Transmodernity: Journal of Peripheral Cultural Production of the Luso-Hispanic World 1(3): 11-27. 